\title{
Fast-Food Restoranlarda Bireyselleştirme, Müş̧teri Tatmini, Minnettarlık ve Tekrar Satın Alma Eğilimi Arasındaki İlişki: Tekrar Satın Alma Eğiliminde Ataletin Farklılaştırıcı Etkisi
}

\author{
The Relationship Between Customization, Customer Satisfaction, Gratitude and \\ Repurchase Intention in The Fast Food Restaurants: The Moderating Effect of Inertia on \\ Repurchase Intention
}

Selma MEYDAN UYGUR ${ }^{1}$, Kemal Gürkan KÜÇÜKERGIN²

\section{ÖZET}

$\mathrm{Bu}$ araştırmada, fast-food restoranlarda bireyselleştirme faaliyetlerinin müşteri tatmini ve minnettarlık üzerinde etkisi araştırılmıştır. Bunu takiben müşteri tatmini ve minnettarlığın tekrar satın alma eğilimi üzerindeki etkisi araştırıımıştır. Ayrıca tekrar satın alma eğiliminin orta çıkmasında ataletin farklılaştırıcı etkisi de araştırılmıştır. Bu amaçların gerçekleştirilmesi için Ankara'nın Gölbaşı ilçesinde yer alan iki adet fast-food restoranın müşterilerinden anket formu aracılığı ile veri toplanmıştır. Toplamda 386 adet kullanılabilir anket elde edilmiştir. Analizler sonucunda; bireyselleştirmenin müşteri tatmini ve minnettarlık üzerinde, minnettarlık ve müșteri tatmininin de tekrar satın alma eğilimi üzerinde olumlu yönde etkilerinin olduğu gözlenmiştir. Müşteri tatmini ve tekrar satın alma eğilimi arasındaki ilişki için ataletin farkılış̧tıııı etkisi tespit edilmemiştir. Fakat minnettarlık ve tekrar satın alma eğilimi arasındaki ilişski incelendiğinde bu ilişkinin düşük atalet düzeyindeki grup için daha güçlü olduğu tespit edilmiştir.

Anahtar Kelimeler: Bireyselleştirme, müşteri tatmini, minnettarlık, tekrar satın alma eğilimi, atalet, fast-food restoranlar.

\section{GiRiş}

Türkiye'de 1980'lerden bu yana fast-food endüstrisinde büyüme gerçekleşmektedir ve birçok genç dışarıda yemek, yakın çevresi ile iletişim kurmak için bu restoranları tercih etmektedir (Akbay vd. 2007: 905). Fast food restoranlarının sayısı artış gösterdikçe, işletmelerin arasındaki rekabet de artmaktadır. Müşteriler ise bu durumda daha yüksek kalitede mal veya hizmet beklentisine girmektedir.

Müşterilerin, daha yüksek kalitede mal ve hizmet beklentilerine ek olarak, bireyselleştirme noktasında da beklentilerinde artış söz konusudur (Kotler,

\begin{abstract}
In this research, the effect of customization in fast-food restaurants on consumer satisfaction and gratitude was investigated. Following, the effect of consumer satisfaction and gratitude on repurchase intention was examined. Besides, moderating effect of inertia on repurchase intention was explored. To this end, data was collected through a questionnaire in two fast-food restaurant in Gölbaşı, Ankara. The study took into consideration 386 questionnaires. Results of the research indicate that, customization had positive effect on consumer satisfaction and gratitude. Additionally, consumer satisfaction and gratitude had positive effect on repruchase intention. There was no significant moderating effect of inertia on the relationship between consumer satisfaction and repurchase intention. But, when the relationship between gratitude and repurchase intention was investigated, the relationship was stronger for the group with low inertia.
\end{abstract}

Keywords: Customization, customer satisfaction, gratitude, repurchase intention, inertia, fast-food restaurants.

2000:15). Gilmore ve Pine II (1997)'nin çalışmalarında belirttiği gibi, bireyselleştirme farklı biçimlerde yapılabilmektedir. Ürünün, sürecin en başında müşterinin ihtiyaçlarına göre şekillenmesi ile bireyselleştirme yapılabileceği gibi; müşterilerin ihtiyaçlarının tespit edilmesi ve bu unsurların eklenmesi ile müşterileri doğrudan bilgilendirmeden de bireyselleştirme yapılabilir.

$\mathrm{Bu}$ araştırmada bahsi geçen bireyselleştirme kavramı, daha ziyade restoranların menülerinde yer alan yiyecek ve içeceklere müşterilerin istediği şekilde yapılan eklemeler veya çıkartmalar olarak ele alınmıştır. Ancak, yapılan bu bireyselleştirme işleminin müşte-

' Doç. Dr., Gazi Üniversitesi, Turizm Fakültesi, Turizm İşletmeciliği Bölümü, smeydan@gazi.edu.tr

${ }^{2}$ Araş. Gör., Gazi Üniversitesi, Turizm Fakültesi, Turizm İşletmeciliği Bölümü, kemalgurkan@nevsehir.edu.tr 
rilerin ihtiyaçlarını tatmin etmesi gerekmektedir. Bu nedenle, bireyselleştirmenin müşteri tatmini üzerindeki etkisi bu araştırma kapsamında değerlendirilmiştir. Müşteri tatmini; müşterilerin beklentilerinin karşılanması durumu olarak açıklanabilir. Bireyselleştirme faaliyetleri de beklentiler ile yakın ilişkili olduğundan dolayı, bireyselleştirme çabalarının müşteri tatminini olumlu yönde etkilemesi beklenebilir. Ayrıca, bireyselleştirmede kişiye özel olarak gösterilen bir çaba söz konusu olduğu için, bu eylemin müşterilerin minnettarlık durumlarına etkisi de araştırılmıştır. Minnettarlık kavramında, kişinin kendisine yapılan bir eylemden dolayı kendini borçlu hissetmesi söz konusu olmaktadır. Kişiye özel bir sunulmuş olan hizmetin minnettarlık oluşturması beklenebilir.

Satın alma davranışı, işletmeler için doğrudan ve somut getiriler oluşturmaktadır (Kumar ve Shah, 2004:320). Bu yüzden, hem minnettarlığın hem de tatminin müşterilerin tekrar satın alma davranışları üzerindeki etkisinin tespit edilmesi amaçlanmışır. Ancak bu aşamada, tekrar satın alma eyleminde rol oynayan bir unsur olarak ataletin de dikkate alınması gerekmektedir. Yanamandram ve White (2006:168), ataleti müşterilerin tembel ve pasif yapılarından dolayı tekrarlı satın almalarını açıklayan bir kavram olarak ele almıştır. Yüksek atalet düzeyindeki kişiler için, tekrar satın alma eyleminin sebebi daha ziyade alışkanlık temelinde ele alınmaktadır. Bu durumda işletme ile müşteri arasındaki ilişki güçlü olmamaktadır (Gounaris ve Stathakopoluos, 2004:286). Bu yüzden atalet düzeyi düşük olanlar için, atalet düzeyi yüksek olanlara göre tatminin ve minnettarlığın tekrar satın alma eğilimi üzerindeki etkisinin daha güçlü olması beklenebilir. Görüldüğü üzere bu çalışma hem kavramların arasındaki ilişkilerin görülmesine, hem de ortaya konulan ilişkilere göre işletmelerin ne gibi faaliyetlerde bulunabileceğine de katkı sağlayacaktır. Ayrıca ortaya konulan ilişkilere göre işletmelerin ne gibi faaliyetlerde bulunabileceği konusunda öneriler geliştirilebilmesi için faydalı olacaktır.

Çalışmanın bir sonraki kısmında, araştırma kapsamında kullanılan kavramlar ve bunlar arasındaki ilişkiler incelenmiştir. Kavramların tanımlarına ve aralarındaki ilişki yapılarına göre hipotezler kurulmuştur ve araştırma modeli ortaya konulmuştur. Bir sonraki bölümde araştırmanın yöntemine ilişkin bilgiler verilmiştir. Bahsi geçen bilgileri takiben, araştırmaya ilişkin bulgular sunulmuştur. Sonuçlar ve öneriler kısmında ise bu araştırmanın bulguları ile literatürdeki bulgular karşılaştııılmıştır. Bunlara uyumlu olarak da önerilerde bulunulmuştur.

\section{LITERATÜRÜN INNCELENMESI}

\subsection{Bireyselleştirme}

Bireyselleştirme, herkese aynı teklifi aynı şekilde sunmaktansa, iletilerin ve tekliflerin kişiye özgü olarak düzenlenmesidir (Kotler, 2000:15,16). Görüldüğü üzere, belirli müşterilerin belirli intiyaçlarını karşılamak pazarlama faaliyetlerinin odak noktası haline gelişmiştir (Loudon vd., 2005:1).

Geleneksel pazarlamada, müşterilerin tam bir tatmin durumuna ulaşması sıklıkla görülen bir sonuç değildir. Bunun sebebi olarak da müşterilerin tam olarak istediği ile işletmelerin teklifleri arasındaki fark gösterilebilir. Bireyselleştirilmiş mal ve hizmetleri sunmak, bu eksikliği giderebilmektedir (Odabaşı, 2012:197). Öztürk vd. (2012:235) de bu belirtilenlere paralel olarak; bireyselleştirme kavramı kapsamında, sunulan hizmetlerin kişiye özel bir hale getirilmesinin mümkün olduğunu belirtmiştir.

Hizmetlerin sunumu esnasında, çalışanların müşteri tercihlerine karşılık vermesi bireyselleştirmeyi ortaya çıkarmaktadır. Örnek olarak, menüdeki sunumlar müşterilerin tercihlerine göre şekillenebilir (Mattila ve Ro, 2008:304).

Kitlesel bireyselleştirme, kitlesel bir temelde her bir müşterinin ihtiyaçlarını karşılamak için bireysel olarak düzenlenmiş ürünler ve iletişim süreçlerinin hazırlanabilmesi ile ilgili bir beceridir. Bireyselleştirme faaliyetlerinde; müşterilerin, satın aldıkları ürünleri şekillendirmeleri söz konusudur (Kotler, 2000:146,158).

Homojen bir pazara ve ortalama tekliflere odaklanmaktansa, müşterilerin ihtiyaçlarındaki farklıııklara odaklanılması önem arz etmektedir. Bu faaliyetlerde etkili olmak için işletmenin sunduğu teklifler ile müşterinin gerçekte ne arzu ettiği arasındaki boşluğa odaklanılması gerekmektedir. Görüldüğü üzere; bireyselleştirme anlayışı, müşteri ihtiyaçlarının çeşitlilik göstermesinden dolayı yönetilmesi zor bir süreçtir. Bireyselleştirme, deneme yanılıma yoluyla değil, gerektiği zaman yapılması gereken bir uygulamadır (Gilmore ve Pine II, 1997:91,95,96).

\subsection{Müşteri Tatmini}

Genel anlamı ile tatmin, "bir ürün ya da hizmet ile ilgili olarak, satın alma eyleminden önceki beklenti çerçevesinde, satın alma eyleminden sonra yaşanan deneyimin tatmin edici olması durumu " olarak açıklanmaktadır (Vavra, 1999:51). Oliver (1999:34) tatmini "tüketicinin ihtiyaç, arzu veya amaçlarını yerine getiren ya da bunları aşan tüketimlerinin değerlendirilmesi ve bu işlemin memnun edici olmasıdır" biçiminde açıklamıştır. 
Fast-Food Restoranlarda Bireyselleştirme, Müşteri Tatmini, Minnettarlık ve Tekrar Satın Alma Eğilimi Arasındaki illişki: Tekrar Satın Alma Eğiliminde Ataletin Farklılaştırıcı Etkisi

Müşteri tatmini, müşteriyi elde tutma ve müşterilerin tekrar satın alma oranlarını arttırmaktadır (Selvi ve Ercan, 2006:181). Buna bağlı olarak müşterilerin sadık birer müşteri haline gelmeleri sağlanmaktadır (Song vd., 2012:461).

Müşteri tatmini, bir kuruluşun şimdiki ve belki gelecekteki varlığını sürdürmesinde önemli bir rol oynamaktadır (Vavra, 1999: 23). Bu yüzden müşteri tatmininin iyi bir biçimde anlaşılması gerekmektedir. $\mathrm{Bu}$ şekilde işletmeler müşterilerin tatmin düzeylerini takip edebilir. Sonucunda da müşterilerin ne gibi davranışsal eğilimlerde bulunacağını tahmin edebilir. Fakat müşteri tatmininin, müşteri davranışları üzerinde tek belirleyici olmadığının da dikkate alınması gerekmektedir.

\subsection{Minnettarlık}

Hemen hemen her kültürde ve insanlık tarihi boyunca minnettarlık bireyselliğin ve sosyal yaşamın normal ve normatif bir görünümü olarak ele alınmıştır (McCullough vd., 2001:250). Minnettarlık, sözlükte "yapılan bir iyiliğe karşı kendini borçlu sayma, gönül borcu" olarak açıklanmaktadır (TDK, 2012).

McCullough vd. (2001:250), minnettarlığın hem ahlaki bir davranışın karşılığı olduğunu hem de ahlaki bir davranışın güdüleyicisi olduğunu belirtmiştir. İnsanlar, diğer insanların kendisine iyilik yaptığı durumlarda, buna minnettarlık ile karşılık vermektedir. Kolyenikova vd. (2009:201), satın alma eyleminin müşterilerin minnettarlıklarını bildirmelerinde bir yol olabileceğini belirtmiştir.

Restoranlar müşterilerine, beklenilenden daha fazla fayda sunduklarında, restoranların maliyetleri ve müşterilerin bu süreçten sağladıkları fayda artmaktadır. Böylece ortaya bir dengesizlik çıkmaktadır. $\mathrm{Bu}$ yüzden müşteriler, restoranların fazladan harcadıkları çabayı dikkate alarak, restoranlara minnettarIık duymaktadır. Bu borçlu olma hissi müşteriler üzerinde baskı oluşturmaktadır. Bu his de müşterilerin restoranları tekrar ziyaret etmelerinde etkili bir unsur olmaktadır (Kim ve Lee, 2013:2).

\subsection{Tekrar Satın Alma Eğilimi}

Davranışsal eğilimler genel olarak tekrar satın alma eğilimi veya ağızdan ağıza pazarlama ile açıklanmaktadır(Assael, 1992:197; Shiffman ve Kanuk, 2000:205; Sun ve Qu, 2011:212).

Wu vd. (2012:2), çevrimiçi mağazalar kapsamında tekrar satın alma eğilimi hususunu bir çevrimiçi mağazanın tekrar müşterisi olmak ile ilgili müşterilerin öznel olasılıkları ve satın alma eyleminin birincil belirleyicisi olarak açıklamıştır.
Griffin (1995:34,35), tekrar satın almada bulunan müşterileri ilk kez gelen müşterilerden ayırarak, bu grubun iki veya daha fazla aynı işletemeden mal veya hizmet satın aldığını belirtmiştir. Bu araştırma kapsamında, davranışsal eğilimlerin bir unsuru olarak açıklanan tekrar satın alma eğilimi kullanılmıştır.

\subsection{Atalet}

Sosyal bilimlerde atalet, eylemsel yetenek noktasında zayıflık olarak kullanılmaktadır. Harekete geçmemek, yılgınlık gibi durumlarla ile açıklanmaktadır (Sekman, 2010:36). Zeelenberg ve Pieters (2004:449) de ataleti "amaç doğrultusundaki davranışların yokluğu" olarak açıklamıştır.

İnsanların, sığınmak istedikleri rahatlık alanları vardır. Müşteriler açısından da aynı durumun geçerli olduğu söylenebilir. Üşenmek, rahat ve kolay olanı tercih etmek genel olarak görülen bir eğilimdir (Kaya, 2010:177).

Atalet düzeyi yüksek olan müşteriler, geçmişte yapmış oldukları satın alma eylemlerinin gelecekteki satın alma eylemleri için en iyi açıklayıcı olduğu kanısındadır. Bu nedenle, müşteriler markalara karşı ciddi bir tutum göstermeseler dahi aynı markaya satın almaya devam eder ve bu şekilde riski azaltmayı umar. Böyle davranarak müşteriler, bilgi edinmek için çaba sarf etmemiş olur. Atalet temelinde eylemde bulunan müşterilerin davranışlarının nedeni geçmiş deneyimlerinden kaynaklanmaktadır (Bozzo, 2002:2,3,4,9).

Atalet temelinde sadakat gösteren müşterilerin satın alma davranışları duygusal bağlılık ile ilişkili değildir. Bu durumda işletme ile müşteri arasındaki ilişki güçlü olmamaktadır (Gounaris ve Stathakopoluos, 2004:286).

\subsection{Bireyselleştirme, Müşteri Tatmini, Minnettarlık ve Tekrar Satın Alma Eğilimi Arasındaki İlişkiler}

Kim ve Lee (2013:8) araştırmalarında, ilişkisel faydaların bir unsuru olarak özel ilgiyi esas almıştır. İlişkisel faydalar, minnettarlık üzerinde olumlu yönde bir etkiye sahipken, tatmin üzerinden anlamlı bir etkiye sahip değildir. Bu araştırmada ise ilişkisel faydalar ve özel ilgi kavramlarından farklı olarak bireyselleştirme kavramı ele alınmıştır. Kotler (2000:146)'in belirttiği üzere bireyselleştirme ihtiyaçları karşılamaya odaklanmış bir kavramdır. Coelho ve Henseler (2012:344) de bireyselleştirmenin tatmini olumlu yönde etkilediğini tespit etmiştir. Bu tespitlere göre bireyselleştirme faaliyetlerinin, müşteri tatmini ve minnettarlık üzerinde olumlu yönde bir etki göstermesi beklenebilir. 
Kim ve Lee (2013:8) ayrıca minnettarlığın, karşılık davranışı üzerinde olumlu yönde bir etkisi olduğunu belirtmiştir. Kolyenikova vd. (2009:208), erkeklerde minnettarlığın harcama miktarını olumlu yönde etkilediğini tespit etmiştir. Kadınlar için bu etki anlamlı değildir. Kale ve Doğan (2006:565), tatminin tekrar ziyaret niyetini; Song vd. (2012:469), tatminin sadakati olumlu yönde etkilediğini tespit etmiştir. Bansal ve Taylor(1999:213) tatmin düzeyinin artışına bağlı olarak işletmenin değiştirilmesi davranışının azaldığını gözlemlemiştir. Yapılan çalışmalar incelendiğinde; müşteri tatmini ve minnettarlığın, müşterilerin tekrar satın alma eğilimlerini olumlu yönde etkilemesi beklenebilir. Bu bilgilerden yola çıkarak aşağıdaki hipotezler geliştirilmiştir.

$\mathrm{H}_{1}$ : Bireyselleştirmenin, müşteri tatmini üzerinde olumlu yönde bir etkisi vardır.

$\mathrm{H}_{2}$ : Bireyselleştirmenin, minnettarlık üzerinde olumlu yönde bir etkisi vardır.

$\mathrm{H}_{3}$ : Müşteri tatmininin tekrar satın alma eğilimi üzerinde olumlu yönde bir etkisi vardır.

$\mathrm{H}_{4}$ : Minnettarlığın, tekrar satın alma eğilimi üzerinde olumlu yönde bir etkisi vardır.
Han vd. (2011b:1016), araştırmalarında, müşteri tatmini ve tekrar ziyaret eğilimi arasındaki ilişkide ataletin farklılaştırıcı bir rol oynadığını tespit etmiştir. Bu ilişki düşük atalet düzeyindeki grup için daha kuvvetli olarak tespit edilmiştir. Benzer biçimde Anderson ve Srinivasan (2003:127) da tatminin sadakate etkisinde ataleti farklılaştırıcı bir değişken olarak kullanmıştır. Bu yüzden davranışların veya davranışsal eğilimlerin belirlenmesinde rol oynayan değişkenlerin atalet düzeyine göre farklı biçimlerde etkide bulunabileceği görülmektedir. Bu bilgilerden yola çıkarak, tekrar satın alma eğiliminin bir belirleyicisi olarak minnettarlığın etkisinin düşük atalet düzeyinde daha güçlü olabileceği öne sürülebilir. Belirtilenler ile uyumlu olarak aşağıdaki hipotezler geliştirilmiştir.

$\mathrm{H}_{5}$ :Müşteri tatmini ile tekrar satın alma eğilimi arasındaki ilişki, düşük atalet düzeyindeki grup için yüksek atalet düzeyindeki gruba göre daha güçlüdür.

$\mathrm{H}_{6}$ : Minnettarlık ile tekrar satın alma eğilimi arasındaki ilişki, düşük atalet düzeyindeki grup için yüksek atalet düzeyindeki gruba göre daha güçlüdür. Bu hipotezler ile uyumlu olarak araştırma modeli geliştirilmiştir. Araştırma modeli Şekil 1'de gösterilmiştir.

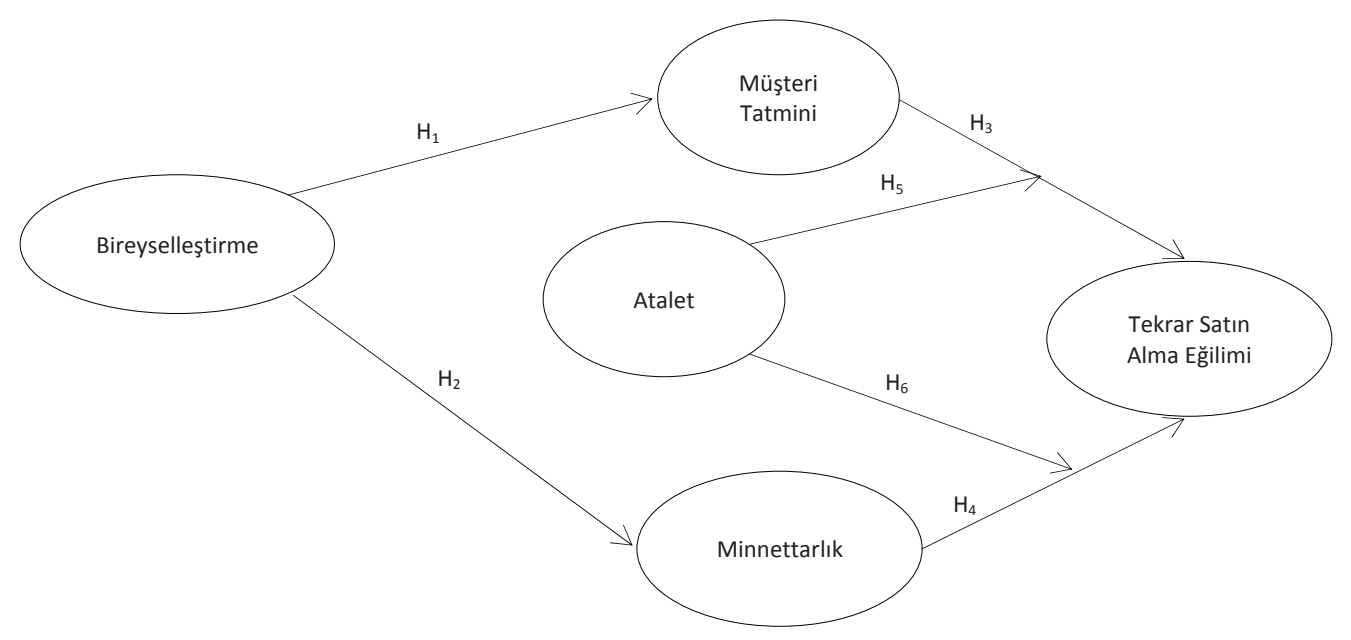

Şekil 1: Araştırma Modeli

\section{ARAŞTIRMANIN YÖNTEMI}

\section{1. Örneklem Grubunun Seçilmesi}

Çalışmanın evreni olarak, Ankara'nın Gölbaşı ilçesindeki fast-food restoranların müşterileri seçilmiştir. Evrenin sayısı bilenemediğinden dolayı örneklem sayısı " $\mathrm{n}=\pi(1-\pi) /(\mathrm{e} / \mathrm{Z})^{2 \prime \prime}$ formülü ile hesaplanmıştır. Evreni temsil edecek olan örnek büyüklüğü \%95 güvenle, \%5 hata payı ile hesaplanmıştır. Genelde, evrenin standart sapma veya varyanslarının bilinmesi olanaksız olduğundan " $\pi(1-\pi)$ 'nin" en yüksek olduğu $(0.5$ X $0.5=0.25)$ değer esas alınabilir (Kurtuluş, 2010: 67). Bu şekilde örnek büyüklüğü 384 olarak hesaplanmıştır. Örnekleme yöntemi olarak, kolayda örnekleme kullanılmıştır. 
Fast-Food Restoranlarda Bireyselleştirme, Müşteri Tatmini, Minnettarık ve Tekrar Satın Alma Eğilimi Arasındaki i̇lişki: Tekrar Satın Alma Eğiliminde Ataletin Farklılaştırıcı Etkisi

\subsection{Verilerin Toplanması}

Verilerin toplanması için, fast-food restoranlarının müşterilerine yönelik olarak bir anket formu derlenmiştir. Anket formunda yer alan ifadeler için Coelho ve Henseler, (2012), Back ve Parks (2003), Cronin vd. (2000), Han vd. (2011b), Ryu ve Han (2011), Kim ve Moon (2009) ve Kim ve Lee (2013)'nin çalışmalarından faydalanılmıştır. Bu ifadeler, anket formunun ilk kısmını oluşturmaktadır. Anket formunun ikinci kısmında ise katılımcıların demografik özelliklerinin tespit edilmesine yönelik sorulara yer verilmiştir. İfadelerde beşli Likert ölçeği kullanılmıştır.

Anketler 2012 yılının Kasım ayında restoranlarda yiyecek-içecek tüketiminde bulunan müşterilere yönelik olarak uygulanmıştır. Toplam olarak 386 adet kullanılabilir anket elde edilmiştir. Çalışmanın Gölbaşı ilçesinde yer alan iki adet restoranla sınırlandırılmış olması, araştırmanın önemli bir kısıtıdır.

\subsection{Verilerin Analizi}

Verilerin analiz edilmesi için, yapısal eşitlik modellemesi(YEM) kullanılmıştır. Böylece önceden belirlenen ilişki örüntülerinin veriler tarafından doğrulanıp doğrulanmadığının tespit edilmesi amaçlanmıştır (Şimşek, 2007:1).
Kestirim metodu olarak en yüksek olabilirlik kestirim yöntemi kullanılmıştır. Ancak bu yöntemin kullanılması için verilerin normal dağılımının söz konusu olmasına gerek vardır (Kline, 2011:154,155). Buna istinaden, çarpıklık ve basıklık katsayılarının \pm 2 değerini aşmaması gerekmektedir (Kunan, 1998:313). Bu araştırmadaki basıklık ve çarpıklık değerleri belirtilen sınırlar dahilindedir.

\section{BULGULAR}

\subsection{Katılımcıların Demografik Bilgileri}

Araştırmaya 386 kişi katılmıştır. Katılımcıların, \%54'ü kadındır, \%91'i 16-24 yaş arasındadır ve \%92'si bekardır. Katılımcıların \%56'sının eğitim durumu ise lisans düzeyindedir ve \%96'sı 2000 TL ve altında bir gelire sahiptir. Görüldüğü üzere bu restoranları tercih etmiş olan kişilerin, çoğunluğunu gençler oluşturmaktadır.

\section{2. Ölçüm Modeli}

Anderson ve Gerbing (1998:422), yapısal eşitlik modellemesi için iki aşamalı yaklaşımı tavsiye etmektedir. Bunun için, öncelikli olarak doğrulayıcı faktör analizi (DFA) yapılmıştır. Yapılan analize ilişkin sonuçlar Tablo-1'de verilmiştir. Tablo'da faktör yüklerine, bu faktör yüklerine ilişkin t değerlerine ve ölçüm modeline ilişkin uyum değerlerine yer verilmiştir.

Tablo 1: Ölçüm Modeli

\begin{tabular}{|c|c|c|c|}
\hline Boyutlar & İfadeler & $\begin{array}{l}\text { Faktör } \\
\text { Yükleri }\end{array}$ & t değerleri \\
\hline \multirow{3}{*}{ Bireyselleştirme } & Bu restoran benim özel ihtiyaçlarımı dikkate alan ürünler sunmaktadır. & .71 & Sabitlendi* \\
\hline & Bu restoran, diğer restoranlarda bulamayacağım ürünler sunmaktadır. & .74 & 11.93 \\
\hline & $\begin{array}{l}\text { Eğer başka bir restorana gidersem, buradaki gibi bana uygun ürünler } \\
\text { bulamam. }\end{array}$ & .68 & 11.04 \\
\hline \multirow{3}{*}{ Müşteri Tatmini } & Bu restoranı seçtiğimden dolayı mutluyum. & .75 & Sabitlendi* \\
\hline & Bu restoranı seçmekle doğru bir karar verdiğimi düşünüyorum. & .77 & 13.78 \\
\hline & $\begin{array}{l}\text { Genel olarak, bu restoranın yiyecek ve içecek hizmetinden tatmin } \\
\text { oldum. }\end{array}$ & .66 & 11.85 \\
\hline \multirow{3}{*}{ Minnettarlık } & Bu restoranı, benim özel isteklerime yanıt verdiği için takdir ederim. & .75 & Sabitlendi* \\
\hline & Bu restorana sunduğu hizmetten dolayı kendimi borçlu hissediyorum. & .61 & 10.35 \\
\hline & Bu restorana, göstermiş olduğu fazladan çabadan dolayı müteşekkirim. & .83 & 12.71 \\
\hline \multirow{3}{*}{$\begin{array}{l}\text { Tekrar Satın Alma } \\
\qquad \text { Eğilimi }\end{array}$} & Bu restoranı daha sık ziyaret edeceğim. & .73 & Sabitlendi* \\
\hline & Yakın gelecekte yine bu restorana gelmek istiyorum & .68 & 12.15 \\
\hline & Diğer restoranlar içerisinde bu restoran benim ilk tercihim olacak. & .72 & 12.71 \\
\hline \multirow{3}{*}{ Atalet } & Bu restoranı değiştirip başka bir restoranı seçmek zahmetli olurdu. & .60 & Sabitlendi* \\
\hline & Restoran tercihimi değiştirmenin zaman açısından maliyeti yüksektir. & .71 & 9.46 \\
\hline & Restoran tercihimi değiştirmek çok çaba harcamamı gerektirmektedir. & .79 & 9.30 \\
\hline Uyum Değerleri & $\chi^{2}=159.75, \mathrm{sd}=80, \chi^{2} / \mathrm{sd}=2.00 \mathrm{RMSEA}=.051, \mathrm{CFI}=.96$ & & \\
\hline
\end{tabular}

Tablo-1 incelendiğinde ölçüm modeline ilişkin uyum değerlerinin kabul edilebilir olduğu görülmektedir (bkz. Engel vd., 2003:52; Sümer, 2000:62). Bu değerlere ek olarak, yapı güvenirliği ve açıklanan var- yans da hesaplanmıştır. Sonrasında ise ayırt edici geçerlik kontrol edilmiştir. Bununla ilgili sonuçlar Tablo2'de yer almaktadır. 
Tablo 2: Örtük Değişkenler Arası Korelasyon Katsayıları, Yapı Geçerliği ve Açıklanan Varyanslar

\begin{tabular}{|l|c|c|c|c|c|}
\hline & Bireyselleştirme & $\begin{array}{c}\text { Müssteri } \\
\text { Tatmini }\end{array}$ & Minnettarlık & TSE & Atalet \\
\hline Bireyselleştirme & $.75(.50)$ & & & & \\
\hline Müşteri Tatmini & .74 & $.77(53)$ & & & \\
\hline Minnettarlık & .47 & .51 & $.78(54)$ & & \\
\hline TSE & .63 & .85 & .71 & $.75(.50)$ & \\
\hline Atalet & .47 & .31 & .20 & .38 & $.74(.50)$ \\
\hline
\end{tabular}

(Not: Koyu değerler yapı güvenirliğini, parantez içindeki değerler ise açıklanan varyans değerlerini göstermektedir.)

Tablo-2 incelendiğinde, yapı güvenirliği değerleri Bagozzi ve Yi (1988:80)'nin belirttiği .60 sınırının, açıklanan varyans değerleri ise Fornell ve Locker (1981: 46)'ın belirttiği .50'nin üzerindedir. Ayırt edici geçerliliğin sağlanması için ise faktörler arasındaki korelasyonun .90 değerini aşmaması gerekmektedir (Kline, 2011:116). Bu yüzden, ayırt edici geçerliliğin de sağlandığı görülmektedir.

\subsection{Yapısal Eşitlik Modeli (YEM)}

İlk aşamada, ölçüm modeli için geçerlilik ve güvenirlik sağlandığından dolayı ikinci aşamada YEM'e geçilmiştir. Bu analizin sonuçları Tablo-3'de yer almaktadır.

Tablo 3: Yapısal Eşitlik Modeline Iliş̧kin Sonuçlar

\begin{tabular}{|l|c|c|c|}
\hline \multicolumn{1}{|c|}{ Hipotezler } & $\begin{array}{c}\text { Standartlaştırılmış } \\
\text { Yol } \\
\text { Katsayıları }\end{array}$ & t Değerleri & Sonuç \\
\hline $\mathrm{H}_{1}$ Bireyselleştirme $\rightarrow$ M.Tat & .75 & 8.78 & Kabul \\
\hline $\mathrm{H}_{2}$ Bireyselleştrime $\rightarrow$ Min & .51 & 7.49 & Kabul \\
\hline $\mathrm{H}_{3}$ M. Tat $\rightarrow$ Tek. Sat. E. & .65 & 8.59 & Kabul \\
\hline $\mathrm{H}_{4}$ Min $\rightarrow$ Tek. Sat .E. & .42 & 6.92 & $\mathrm{Kabul}$ \\
\hline Müşteri Tatmini $\mathrm{R}^{2}=.57$ & Uyum Değerleri & $\begin{array}{c}\chi^{2}=121.29, \mathrm{sd}=50 \chi^{2} / \mathrm{sd}=2.45, \\
\text { RMSEA }=.061, \mathrm{CFI}=.96\end{array}$ \\
\hline Minnettarlık $\mathrm{R}^{2}=.26$ & \multicolumn{3}{|l}{} \\
\hline Tekrar Sat. A. $\mathrm{R}^{2}=.81$ &
\end{tabular}

Tablo 3 incelendiğinde bireyselleştirmenin, müşteri tatmini üzerindeki etkisi olumlu yöndedir ve anlamlıdır $(\beta=.75, p<.01)$. Bu nedenle, $\mathrm{H} 1$ desteklenmiştir. Bireyselleştirmenin, minnettarlık üzerindeki etkisi de olumlu yöndedir ve anlamlıdır $(\beta=.51, p<$ .01). Böylece, $\mathrm{H} 2$ desteklenmiştir. Müşteri tatmininin, tekrar satın alma eğilimi üzerinde olumlu bir etkisinin olduğu gözlenmiştir ve bu etki anlamlıdır $(\beta=.65$, $\mathrm{p}<$.01). Bu nedenle, H3 desteklenmiştir. Aynı şekilde, minnettarlığın da tekrar satın alma eğilimi üzerinde olumlu yöndeki etkisi anlamlıdır ( $\beta=.41, p<.01)$. Böylece, $\mathrm{H} 4$ desteklenmiştir.

\subsubsection{Farklılaştırıcı Etkinin Tespit Edilmesi}

Bu aşamada ilk olarak, müşteriler atalet düzeylerine göre k-ortalamalar yöntemi ile iki gruba ayrılmıştır. Bu gruplar; düşük (215 kişi) ve yüksek (171 kişi) atalet düzeyindekiler şeklinde ifade edilebilir.

Hipotezlerin test edilmesine geçilmeden önce, tüm değerlerin serbest bir biçimde tahmin edildiği "temel model" test edilmiştir. Ardından "metrik farksızlık" modeli test edilmiştir. Hair vd. (2009:743) farkIılaştırıcı etkinin ölçülmesi için, metrik farksızlık testinin gerekli olduğunu belirtmiştir. Bu modelde faktör yükleri her iki grup için de eşit olarak hesaplanmaktadır. Bu işlemlerin sonuçları Tablo-4'de sunulmuştur.

Tablo 4: Ölçüm Modeli Farksızık Testi

\begin{tabular}{|l|c|c|c|c|c|c|}
\hline Modeller & $\chi^{2}$ & $\mathrm{df}$ & RMSEA & CFI & $\Delta \chi^{2}$ & Metrik Farksızlık Durumu \\
\hline Temel Model & 183.41 & 96 & .049 & .95 & $\Delta \chi^{2}(8)-14.61 \mathrm{p}>.01$ & Desteklenmiştir \\
\hline $\begin{array}{l}\text { Metrik Farksızlık } \\
\text { Modeli }\end{array}$ & 198.02 & 104 & .049 & .95 & & \\
\hline
\end{tabular}

Íki model arasındaki tespit edilmiş olan farklılık Bagozzi ve Yi (1989:273)'nin belirttiği gibi, bundan anlamlı değildir $\left(\Delta \chi^{2}(16)-14.61 p>.01\right)$. Bu yüzden metrik farksızlık durumu desteklenmiştir. İki model arasında anlamlı bir farklılık olmadığından dolayı, sonraki aşamada faktör yüklerinin her iki grup için de eşit olarak tahminlendiği model (metrik farksızlık modeli) esas alınmıştır. 
Fast-Food Restoranlarda Bireyselleştirme, Müşteri Tatmini, Minnettarık ve Tekrar Satın Alma Eğilimi Arasındaki i̇lişki: Tekrar Satın Alma Eğiliminde Ataletin Farklılaştırıcı Etkisi

Faktör yüklerinin eşitliği tespit edildikten sonra, yapısal farksızlık için gerekli işlemler yapılmıştır. Yüksek ve düşük atalet düzeyindeki gruplar esas alınarak, modeldeki tüm yolları içeren bir temel model oluşturulmuştur. Temel modelde, tüm yollar her iki grup için serbest bir biçimde tahminlenmiştir. Bu model, ataletin farklılaştırıcı etkisini tespit etmek için diğer iki model ile karşılaştırılmıştır. Bu amaçla da ataletin farklılaştırıcı etkisinin ölçülmesinin amaçlandığı yolların değeri, her iki grup için eşit olarak hesaplanmıştır. Eğer modelin uyumu, anlamlı bir biçimde düşüş gösterirse, ilgili değişkeninin farklılaştırıcı etkisi söz konusudur (Hair vd., 2009: 753).

Tablo 5: Yapısal Farksızlık Testi

\begin{tabular}{|c|c|c|c|c|c|c|c|}
\hline \multirow[b]{2}{*}{ Yollar } & \multicolumn{2}{|c|}{$\begin{array}{c}\text { Yüksek Atalet } \\
\text { Düzeyindeki Grup }\end{array}$} & \multicolumn{2}{|c|}{$\begin{array}{c}\text { Düşük Atalet } \\
\text { Düzeyindeki Grup }\end{array}$} & \multirow[b]{2}{*}{ Temel Model } & \multirow[b]{2}{*}{ İç İçe Model } & \multirow[b]{2}{*}{ Fark } \\
\hline & $\begin{array}{c}\text { Standartlaştırılmış } \\
\text { Yol } \\
\text { Katsayıları }\end{array}$ & $\mathrm{t}$ & $\begin{array}{c}\text { Standartlaştırılmış } \\
\text { Yol } \\
\text { Katsayıları }\end{array}$ & $\mathrm{t}$ & & & \\
\hline $\mathrm{MT} \rightarrow \mathrm{TSE}$ & .67 & 6.54 & .59 & 6.47 & $\chi^{2}(108) 217.55$ & $\chi^{2}(109) 220.08$ & $\Delta \chi^{2}(1)-2.53 p>.05$ \\
\hline $\mathrm{MIN} \rightarrow \mathrm{TSE}$ & .34 & 4.03 & .54 & 6.34 & $\chi^{2}(108) 217.55$ & $\chi^{2}(109) 225.25$ & $\Delta \chi^{2}(1)-7.70 \mathrm{p}<.05$ \\
\hline
\end{tabular}

Tablo-5 incelendiğinde, gruplara göre müşteri tatmini ve tekrar satın alma eğilimi için anlamlı bir farklılık tespit edilmemiştir $(\Delta \chi 2(1)-2.53 \mathrm{p}>.05)$. Bu yüzden H5 desteklenmemiştir. Minnettarlıktan, tekrar satın alma eğilimine olan yollar, gruplara göre anlamlı bir farklılık göstermiştir $(\Delta \chi 2(1)-7.70 \mathrm{p}<05)$. Düşük atalet düzeyindeki grup için minnettarlığın tekrar satın alma eğilimi üzerindeki etkisi $(\beta=.54, p<$ $.01)$, yüksek atalet düzeyindeki gruba göre $(\beta=.34$, $\mathrm{p}<.01$ ) daha güçlüdür. Böylece $\mathrm{H} 6$ desteklenmiştir.

\section{SONUÇ VE ÖNERILER}

Bu araştırma kapsamında, fast-food restoranları için ürünlerin kişiye özgü bir biçimde sunulması ile ilgili bir kavram olan bireyselleştirmenin müşterilerin tatmin ve minnettarlıklarına olan etkisi incelenmiştir. Fast-food restoranları için temel ürünler genel olarak aynı kalsa dahi, müşterilerin isteklerine göre ürünlerde uyarlamalar yapılabilmektedir. Bu faaliyetlerdeki başarının etkisi, müşteri tatmini ve minnettarlık üzerinden gözlenebilmektedir. Müşteri tatmini kavramı; beklentilerin karşılanması olarak açıklanmaktayken, minnettarlık kavramı ise insanların kendilerine yönelik gösterilen fazladan bir çabadan dolayı kendini borçlu hissetmeleri olarak açıklanmaktadır. Müşteri tatmini ve minnettarlığın da işletmelere ne gibi fayda sağladığının görülebilmesi için bu iki unsurun tekrar satın alma eğilimi üzerindeki etkisi araştırılmıştır. Tekrar satın alma eğilimi; müşterilerin aynı işletmeden veya aynı mal veya hizmetleri tekrarlı olarak satın almalarına ilişkin bir eğilimi ifade emektedir. Bu çalışma kapsamında tekrar satın alma eğilimi, aynı restorandan tekrarlı bir biçimde satın alma hususunu açıklamaktadır. Tatminin ve minnettarlığın satın alma niyetine etkisi incelenirken, bu ilişkide ataletin farklılaştırıcı etkisi de incelenmiştir. Atalet; Sekman (2010: 36)'ın da belirttiği gibi harekete geçmemek ve yılgınlık gibi durumlar ile açıklanmaktadır. Müşteriler açsından bakıldığında atalet; tembellikten ve bilindik olanı seçme eğiliminden dolayı tekrar aynı işletmeyi tercih etmeleri ile ilgili bir durum olarak açıklanabilir. Genel olarak bu araştırmada bireyselleştirme faaliyetlerinin müşteri tatmini ve minnettarlık; müşteri tatmini ve minnettarlığın ise tekrar satın alma eğilimi üzerindeki etkilerini tespit ederek; müşterilerin satın alma faaliyetlerinin daha iyi bir biçimde anlaşılması amaçlanmıştır.

Belirtilen amaçlarla, Ankara'nın Gölbaşı ilçesindeki fast-food restoranların müşterilerine yönelik bir araştırma gerçekleştirilmiştir. Toplam olarak 386 kişiye ulaşılmıştır. Araştırmada ilk olarak doğrulayıcı faktör analizi yapılmıştır. Ölçüm modelinin iyi bir uyum göstermesinden sonra, güvenirlik ve geçerlik sonuçları da incelenmiştir. Bu aşamadan sonra yapısal eşitlik modellemesine geçilmiştir. Bu şekilde araştırmadaki hipotezler test edilmiştir.

Bireyselleştirmenin, müşteri tatmini üzerindeki etkisinin anlamlı olduğu tespit edilmiştir.. Bu bulgu, Kotler (2000:146)'in; bireyselleştirme ile amaçlananın ihtiyaçların karşılanması olduğuna ilişkin ifadesi ile uyumludur. Ayrica, Coelho ve Henseler (2012:344)'nin bulguları ile de uyumludur. Bireyselleştirmenin, minnettarlık üzerindeki etkisi de anlamlı olarak tespit edilmiştir. Kim ve Lee (2013:8) de ilişkisel faydaların minnettarlık üzerinde olumlu yönde bir etkisi olduğunu tespit etmiştir. Ancak bu iki bulgu birlikte değerlendirildiğinde; bireyselleştirmenin, müşteri tatmini üzerindeki etkisi, minnettarlık üzerindeki etkisine göre daha güçlüdür. Yapılan bireyselleştirme faaliyetlerinin, müşterilerin üzerinde kendilerini borçlu hissettikleri bir duruma yol 
açtığını fakat bu faaliyetlerin etkisinin daha çok, müşterilerin tatmin olmasına yol açtığı söylenebilir. Müşteri tatmininin, beklentilerin karşılanması veya aşılması olarak açıklandığı dikkate alındığında, yapılan bireyselleştirme faaliyetleri bir tatmin durumu meydana getirmiştir. Fakat bu çabaların ortaya çıkardığı minnettarlık hissi tatmine göre daha zayıftır. Bu bağlamda, yapılan bireyselleştirme faaliyetlerinin müşteriler tarafından alışılmışın dışında bir durum olarak değerlendirilmediği söylenebilir. Ancak müşterilere özel ilgi gösterilmesi yoluyla, minnettarlığın arttırılması amaçlanmalıdır.

Müşteri tatminin tekrar satın alma eğilimi üzerindeki olumlu yönde olan etkisinin anlamlı olduğu gözlenmiştir. Bu bulgu, Kale ve Doğan (2006:565), Song vd. (2012:469) ve Bansal ve Taylor (1999:213)'ın çalışmaları ile paraleldir. Minnettarlığın da tekrar satın alma eğilimi üzerindeki etkisi olumlu yönde ve anlamlıdır. Kolyenikova vd. (2009:208) ve Kim ve Lee (2013:8)'nin bulguları bu bulgu ile paraleldir. Bu iki bulgu birlikte değerlendirildiğinde müşterilerin tekrar satın alma eğilimleri üzerinde kendilerini işletmeye karşı borçlu olarak hissetmelerinden ziyade, müşteri tatmininin daha belirleyici olduğu görülmektedir. Çünkü müşteri tatminin tekrar satın alma eğilimi üzerindeki etkisi, minnettarlığın etkisine göre daha güçlüdür. Fast-food restoranlarda, müşterilerin tercihlerini tekrarlama sebeplerinden birisi ihtiyaçların karşılanması hususudur. Bu kitle için, sunulan yiyecek içecek hizmetlerinin tatmin edici olması tercih sebebi olarak oldukça belirleyicidir. Hizmetlerin müşteri üzerinde uyandırdığı minnettarlık hissi, bir diğer ifadeyle özel sunumların müşterilerin kendini borçlu hissetmesi durumu, müşterilerin işletmeyi tekrar tercih etmelerinde daha az belirleyicidir. Öncelik, ihtiyaçların tatmin edilmesi ile ilgilidir.

Çalışma kapsamında, bahsi geçen doğrudan ilişkilerin yanı sıra ataletin farklılaştırıcı etkisi incelendiğinde bu etkiyi müşteri tatmini ile tekrar satın alma eğilim arasında göstermediği tespit edilmiştir. Müşteri tatmini, hem düşük hem de yüksek atalet düzeyinde olan kişiler için tekrar satın alma eğilimi üzerinde farklı bir etkiye sahip değildir. Bu bulgu Han vd. (2011b:105)'in çalışması ile uyumlu değildir. Fast-food müşterileri için, müşteri tatmini atalet düzeyleri ilişkili olmaksızın tekrar satın alma üzerinde belirleyicidir. Bir önceki bulguların yorumlanmasında belirtildiği gibi, müşteri tatmini tekrar satın alma eğilimi üzerinde güçlü bir belirleyicidir. Fakat minnettarlık ile tekrar satın alma ilişkisi incelendiğinde, düşük atalet düzeyinde olan grup için minnettarlık, tekrar satın alma eğiliminin oluşumunda daha belirleyicidir. Söz konusu olan, müşterilerin kendilerini borçlu oldukları için tekrar satın almaları olduğunda, atalet düzeyi yüksek olan kişiler için; atalet düzeyi düşük olan kişilere göre minnettarlık hissi bu konuda daha az belirleyicidir.

Bu sonuçlara göre, fast-food restoranların müşterilerinin tatmin edilmesi noktasında bireyselleştirmeye önem vermeleri gerekmektedir. Bu nedenle, fast-food restoranların yapıları da dikkate alındığında, özellikle siparişlerin alınması esnasında müşterilerin tercihlerinin dikkatli bir biçimde takip edilmesi ve yiyecek-içeceklerin buna göre şekillendirilmesi gerekmektedir. Ürünlerin genel yapısının standart olduğu göz önüne alındığında, küçük ekleme ve çıkartmaların da etkisi önem kazanmaktadır. Bu uygulama, tatmin oluşturmaktaki etkisi kadar olmasa da müşterilerde minnettarlık durumunu da beraberinde getirebilmektedir. Müşterilerin tatmin edilmesinde ve minnettarlık hislerinin oluşturulmasında bireyselleştirme dışında birçok değişkenin etkili olduğu dikkate alınmalıdır(bkz: Kim ve Lee, 2013). Müşterilerin tekrar satın alma eylemlerinde ataletten de bağımsız olarak, müşteri tatmininin önemli bir belirleyici olduğu dikkate alındığında; doğru düzeyde beklenti oluşturmak ve buna denk bir biçimde yiyecek-içecek hizmeti sunmak fastfood restoranlar için oldukça belirleyicidir. Bu yüzden, müşterilerin tatmin düzeyleri takip edilmelidir. Ayrıca bu noktada çalışanların, müşteri tatmini oluşumuna engel olabilecek bazı davranışlarının da engellenmesi gerekmektedir. Minnettarlık atalet düzeyi düştükçe, tekrar satın alma eğilimi üzerinde daha fazla belirleyici olmaktadır. Fakat bir fast-food restoranın elindeki kaynaklar minnettarlık geliştirmek için sınırlıdır. Bu noktada, müşteriye gösterilecek fazladan ilgi ve ikramlar ile bu hissin kuvvetlendirilmesi mümkündür. Ataletin etkili olduğu bireyler için, minnettarlık ve tekrar satın alma eğilimi arasındaki bağın güçlendirilmesi önemlidir fakat bu grup için daha ziyade müşteri tatminine odaklanmak daha faydalı olacaktır.

Bu çalışmanın kısıtlılığı örneklem ile ilgilidir. Sınırlı bir bölgede ve sınırlı sayıda restoran üzerinden yürütülmüş bir çalışma olduğu için, bulguların yorumlanmasında bu hususa dikkat edilmelidir.

Bu konuyla ilgili yapılacak çalışmalar farklı yiyecek-içecek işletmeleri için genişletilmelidir. Çünkü bireysel hizmetin daha belirgin olduğu restoranlarda bireyselleştirmenin etkisi farklı olabilir. Aynı şekilde bu etki tatmin ve minnettarlığa farklı şekillerde yansıyabilir. Ayrıca müşterilerin tekrar satın alma eğilimleri ile ilgili atalet gibi bazı değişim engelleri mevcuttur (bkz; Han vd., 2011a). Bu değişkenlerin de sürece eklenmesi ile beraber, müşterilerin satın alma süreçleri daha iyi bir biçimde anlaşılabilir. 


\section{KAYNAKLAR}

Akbay, C., Tiryaki, G.Y. ve Gul, A. (2007) "Consumer Characteristics Influencing Fast Food Consumption in Turkey” Food Contol, 18(8):904-913.

Anderson, J.C. ve Gerbing, D.W. (1998) "Structural Equation Modeling in Practice: A Review and Recommend Two-Step Approach" Psychological Bulletin, 103(3):411-423.

Anderson, R.E. ve Srinivasan, S. S. (2003) "E-Satisfaction and and E-Loyalty: A Contingency Framework” Psychology \& Marketing, 20(2):123-138.

Assael, H. (1992) "Consumer Behavior \& Marketing Action” 4th Edition, Boston, PWS-KENT Publishing Company.

Back, K.J. ve Parks, S.C. (2003) "A Brand Loyalty Model Involving Cognitive, Affectice, and Conative Brand Loyalty and Customer Satisfaction" Journal of Hospitality \& Tourism Research, 27(4):419-435.

Bagozzi, R.P. ve Yi, Y. (1989) “The Degree of Intention Formation as a Maderator of the AttitudeBehavior Relationship" Social Psychology Quarterly, 52(4):266-279.

Bagozzi, R.P. ve Yi, Y. (1988) "On the Evaluation of Structural Equation Models" Journal of the Academy of Marketing Science, 16(1):74-94.

Bansal, H.S. ve Taylor, S. (1999) "The Service Provider Switching Model(SPSM): A Model of Consumer Switching Behaviour in the Services Industry" Journal of Service Research, 2(2):200-218.

Bozzo, C. (2001) "Understanding Inertia in a Industrial Context" Journal of Customer Behaviour, $1: 335-355$.

Coelho, P.S. ve Henseler, J. (2012) "Creating Customer Loyalty Through Service Customization" European Journal of Marketing, 46(3):331-356.

Cronin, J.J., Brady, M.K. ve Hult, G.T. (2000) "Assessing the Effects of Quality, Value, and Customer Satisfaction on Consumer Behavioral Intentions in Service Environments" Journal of Retailing, 76(2):193218.

Engel, K., Moosbrugger, H. ve Müller, H. (2003) "Evaluating the Fit Structural Equation Models: Tests of Significance and Descriptive Goodness-of-Fit Measures" Methods of Psychological Research Online, 8(2):23-74.

Fornell, C. ve Larcker, D.F. (1981) "Evaluating Structural Equation Models with Unobservable Variables and Measurement Eror" Journal of Marketing, 18(1):39-50.
Gilmore, J.H. ve Pine II, B.J. (1997) “The Four Faces of Mass Customization" Harvard Business Review, 75(1):91-101.

Gounaris, S. ve Stathakopoulos, V. (2004) "Antecedents and Consequences of Brand Loyalty" Brand Management, 11(4):283-306.

Griffin, J. (1995) Customer Loyalty (How to Earn It, How to Keep It), New York, Lexington Books.

Hair, J.F., Black, W.C., Babin, B.J. ve Anderson, R.E. (2009) "Multivariate Data Analysis" 7th Edition, New York, Prentice Hall.

Han, H., Back, K.J. ve Kim, Y.H. (2011a) "A Multidimensional Scale of Switching Barriers in the Full-Service Restaurant Industry" Cornell Hospitality Quarterly, 52(1):54-63.

Han, H., Kim, Y. ve Kim, E.K. (2011b) "Cognitive, Affective, Conative, and Action Loyalty: Testing The Impact of Inertia" International Journal of Hospitality Management, 30(4):1008-1019.

Kale, E. ve Doğan, Ş. (2006) "Kapadokya Destinasyonunda Müşteri Memnuniyeti Ölçülmesi” Çanakkale Onsekiz Mart Üniversitesi III. Lisansüstü Turizm Öğrencileri Kongresi Bildiri Kitabı.

Kaya, İ. (2010) Pazarlama Bi'Tanedir!, İstanbul, Babıali Kültür Yayıncılığı.

Kim, S. ve Lee, J.S. (2013) "Is Satisfaction Enough to Ensure Reciprocity with Upscale Restaurants? The Role of Gratitude Relative of Satisfaction" International Journal of Hospitality Management,33 (1):118-128

Kim, W. G. ve Moon, Y. J. (2009) “Customers' Cognitive, Emotional, and Actionable Response to the Servicescape: A Test of the Moderating Effect of the Restaurant Type" International Journal of Hospitality Management, 28(1):144-156.

Kline, R.B. (2011) Principles and Practice of Structural Equation Modeling 3th Edition, New York, The Goulford Press.

Kolyesnikova, N., Dodd, T.H. ve Wilcox, J.B. (2009) "Gender as a Moderator of Reciprocal Consumer Behavior" Journal of Consumer Marketing, 26(3), 200213.

Kotler, P. (2000) Marketing Management Millenium Edition, 10th Edition, New Jersey, Prentice-Hall.

Kurtuluş, K. (2010) Araştırma Yöntemleri, İstanbul, Türkmen Kitabevi.

Kumar, V. ve Shah, D. (2004) "Building and 
Sustaining Profitable Customer Loyalty for the 21st Century" Journal of Retailing, 80(4):317-330.

Kunan, J.A. (1998) "An Introduction to Structural Equation Modelling for Language Assessment Research" Language Testing, 15(3):295-332.

Loudon, D., Stevens, R. ve Wrenn, B. (2005) Marketing Management Text and Cases, New York, The Haworth Press.

Mattila, A.S. ve Ro, H. (2008) "Customer Satisfaction, Service Failure, and Service Recovery" Oh et al.(eds.) Handbook of Hospitality Marketing Management, Burlington, Butterworth-Heinemann.

McCullough, M.E., Kilpatrick, S.D., Emmons, R.A. ve Larson, D.B. (2001) "Is Gratitude a Moral Affect?" Psychological Bulletin, 127(2):249-266.

Odabaşı, Y.(2012) Post Modern Pazarlama, 3. Baskı, İstanbul, Mediacat.

Oliver, R. L. (1999) “Whence Customer Loyalty" Journal of Marketing, 63:33-44.

Öztürk, S., Coşkun, A. ve Dirsehan T. (2012) "Fırsat Sitelerine Yönelik E-Sadakati Belirleyen Boyutların İncelenmesi, Eskişehir Osmangazi Üniversitesi İktisadi ve Ídari Bilimler Fakültesi Dergisi, 7(2):217-239.

Ryu, K. ve Han, H. (2011) "New or Repeat Customers: How Does Physical Environment Influence Their Restaurant Experience?" International Hospitality Management, 30(3):599-611.

Sekman, M. (2010) Kişsel Ataleti Yenmek, Özel Baskı, İstanbul, Alfa Yayınları.

Selvi, M.S. ve Ercan, F. (2006) “Otel İşletmelerinde Müşteri Sadakatinin Değerlendirilmesi:İstanbul'daki Beş Yıldızlı Otel İşletmelerinde Bir Uygulama” Balıkesir Üniversitesi Sosyal Bilimler Enstitüsü Dergisi, 9(15):159189.

Shiffman, L.G. ve Kanuk, L.L. (2000) Consumer
Behavior 7th Edition, New Jersey, Prentice Hall.

Song, L.B., Veen, R., Li, G. ve Chen, J.L. (2012) "The Hong Kong Tourist Satisfaction Index" Annals of Tourism Research, 39(1):459-479.

Sun, L.B. ve Qu, H. (2011) "Is There Any Gender Effect on the Relationship Between Service Quality and Word-of-Mouth?" Journal of Travel \& Tourism Marketing, 28(2):210-224.

Sümer, N. (2000) "Yapısal Eşitlik Modelleri: Temel Kavramlar ve Örnek Uygulamalar" Türk Psikoloji Yazıları 3(6):49-74.

Şimşek, Ö. (2007) Yapısal Eşitlik Modellemesine Giriş Temel İlkeler ve Lisrel Uygulamaları, Ankara, Ekinoks.

Türk Dil Kurumu (2012), http://www.tdk.gov.tr/, (12.13.2012).

Vavra, T.G. (1999) Müşteri Tatmini Ölçümlerinizi Geliştirmenin Yolları, İstanbul, Kalder Yayınları.

Wu, L.Y., Chen, K.Y., Chen, P.Y. ve Cheng, S.L. (2012) "Perceived Value, Transaction Cost, and Repurchase-Intention in Online Shopping: A Relational Exchange Perspective" Journal of Business Research, http://dx.doi.org/10.1016/j.jbusres.2012.09.007.

Yanamandram, V. ve White, L. (2006) "Switching Barriers in Business-to-Business Services: A Qualitative Study" International Journal of Service Industry Management, 17(2):158-192.

Zeelenberg, M. ve Pieters, R. (2004) "Beyond Valence in Customer Dissatisfaction: A Review and New Findings on Behavioral Responses to Regret and Disappointmen in Failed Services" Journal of Business Research, 57:445-455. 